\title{
AN ERROR ANALYSIS ON SUBJECT-VERB AGREEMENT IN CONSTRUCTING SIMPLE PRESENT TENSE MADE BY THE SECOND SEMESTER STUDENTS OF LAW FACULTY
}

\author{
Meikardo Samuel Prayuda \\ Catholic University of Saint Thomas \\ Email : meikardo_samuel@ust.ac.id
}

\begin{abstract}
This research was aimed to find out the subject-verb agreement error made by the second semester students of Law Faculty UNIKA Santo Thomas. From the findings, $27 \%$ of the instruments answered by the students were identified error. There were 4 kinds of error made by the students in constructing subject-verb agreement. They were omission error, addition error, misformation error, and misordering error. In omission error, there were 26 errors occurred. In addition error, there were 5 errors occurred. In misformation error, there were 54 errors occurred. In misordering error, there was 1 error occurred. Among all of the errors that had been identified, misformation error was the most dominan error faced by the students. Based on the analysis, the possible cause of error was because of the students did not understand well about the construction of the simple present tense mastery. Although only $27 \%$ instrument was identified error, it was considered that the students' lack of knowledge in structure could give serious impact to their writing. It was suggested that the students need to enrich their knowledge at least in the mastery of the simple present tense, specially in the construction of subjectverb agreement. In other hand, the faculty need to make extra class for the English subject to give the students more chance to enhance their English knowledge. This would support the vision of UNIKA Santo Thomas in achieving International Level University.
\end{abstract}

Keywords: error analysis, subject-verb agreement, simple present tense

\section{Introduction}

Language is a fundamental element in life. One of the languages used by most of the people around the world is English. This only reason is more than enough to take English as a language which is important to master. The mastery of English means the ability of the language users in using English in the right manner. It means that the users must be able to master all the four skills of language including speaking, listening, writing, and reading.

Those four skills are the skills needed to master English. However, there is also one fundamental thing that acts as the very foundation of a language which is grammar. Although grammar acts as the very foundation of a language, in fact that language cannot just exist without grammar. It has the main role in the way of language used. Realizing the important role of grammar in the language used, grammar is a must to learn before you start to talk about the four skills of language.

Grammar stands as the rule of language. In short, to master the language specially English, then you need to master the grammar. English grammar has many branches. One of them is tenses. Tenses has a role in dividing the chronology order of the language used. It is divided into present tense, past tense, and future tense. 
In daily use, language users who master English must be able to use English with the right tense. As for the daily activity, present tense must be used correctly. As for the past activity, past tense must be used correctly. As for the future activity, future tense must be used correctly.

Each of the tenses has their own structure or formula. The language then must follow this structure or else the language must not be a good language. Generally, people who wants to learn about tenses start from the basic one which is the simple present tense.

The simple present tense is considered as the easiest one to learn. It talks about the daily activities. People who just learn English must be glad with this simple present tense. The simple present tense formula is the most simple among the other tenses and also the easiest one to understand.

Although it is considered as the easiest one, an observation at one of the class of the second semester students of Law Faculty in UNIKA Santo Thomas Medan showed that some of the students made errors in their simple present tense writing of simple clause. In the observation, they were asked to write down about their daily activities. Most of the errors however occured in the subject-verb agreement. Some of the students made errors in the term of omission where they did not put suitable subject-verb agreement in their writing such as, "Annisa not go to school every Sunday". Another errors also occurred in the term of addition as in, "Diana not eats banana".

After analyzing the observation, it is realized that a further research had been conducted in order to find out the kinds of errors and also the most errors made by the students of Law Faculty in UNIKA Santo Thomas Medan. This research had cleared up what the real obstacle faced by the students of Law Faculty in UNIKA Santo Thomas Medan in constructing the simple present tense.

\section{Writing}

Writing is one of the four skills in English. In writing, the process can achieve a product. Hyland (2003: 4) states that writing is a service activity through which learners can solidify their knowledge of vocabulary and other grammatical structures. Therefore, the goal of writing is twofold. Firstly, it practises the vocabulary and grammar of the lesson (see also Hyland, 2003; Weigle, 2002: 12), and secondly, it helps develop writing ability that serves communicative purposes.

Mertens (2010) states that writing is a complex and cognitively demanding activity. To be successful, writers need an understanding of the components of a quality test as well as knowledge of writing strategies that can be used to shape and organize the writing process.

Kusumaningsih (2001: 1) states that writing is a communicate act, a way of sharing observation, thought, or ideas with ourselves and others. It is a tool of thinking. By writing, we can tell about people, remember the facts and ideas.

Prayuda (2020: 19) states that writing is a communicate act in expressing ideas, issues, events facts, feeling, experience, and thought into written form by using vocabulary and other grammatical structures.

\section{Simple Present Tense}

Simple present tense is one of the tenses used in English Grammar. The purpose of this tense is to tell about things that happen regularly and natural 
phenomenon. It can be about daily activities, weekly activities, monthly activities, yearly activities, and so on. Based on its function, this tense considered as the most important one to learn especially for beginner.

In constructing sentences based on simple presnt tense, learners may use the two formulas of this tense. The first one is the verbal. The function of this formula is to tell actions that require verb in the sentence. The second is the nominal. The nominal can be used to tell things that do not require verb in the sentence. It is used for the construction of sentences which consist of noun, adjective, adverb, or object pronoun. The formulas are as follow:

Verbal

Affirmative

Subject (I, you, we, they) + Verb

Subject (he, she, it) + Verb + s/es

Negative

Subject (I, you, we, they) + Do + Not +Verb

Subject (he, she, it) + Does + Not + Verb

Introgative

Do + Subject (I, you, we, they) + Verb

Does + Subject (he, she, it) + Verb

Nominal

Affirmative

Subject + To Be + Non Verb

Negative

Subject + To Be + Not + Non Verb

Introgative

To Be + Subject + Non Verb

\section{Research Findings}

The data of this research was taken from the students' worksheet. It was then analyzed by analyzing the subject-verb agreement error made by the students in their worksheet. Based on the analysis, the findings could be drawn as follows.

Omission

Table 1. Omission

\begin{tabular}{|l|l|l|l|}
\hline No & Error & Correction & Frequency \\
\hline 1 & $\begin{array}{l}\text { Andi and Susan not always } \\
\text { together. }\end{array}$ & $\begin{array}{l}\text { Andi and Susan are not always } \\
\text { together. }\end{array}$ & 1 \\
\hline 2 & We not wrong. & We are not wrong. & 4 \\
\hline 3 & $\begin{array}{l}\text { The police officer at the } \\
\text { crime scene. }\end{array}$ & $\begin{array}{l}\text { The police officers are not at the } \\
\text { crime scene. }\end{array}$ & 2 \\
\hline 4 & We not innocent. & We are innocent. & 5 \\
\hline 5 & Many books on the bag. & There are many books in the bag. & 4 \\
\hline 6 & Anyone there? & Is anyone there? & 8 \\
\hline 7 & Many books on this book. & There are many books in the bag. & 2 \\
\hline \multicolumn{2}{|l|}{ TOTAL } & 26 \\
\hline
\end{tabular}


From the analysis, it was found out that there were 7 errors in omission with the frequency of occurrence 26 times. The most frequent error appeared to be in the omission of to be. They did not put the suitable to be in constructing the sentences. As on the first instrument, there was an omission of to be are. The subject and verb did not agree based on its rule. It was considered important to add to be are to construct good subject-verb agreement regarding to the number of the subject on that instrument. This fenomena also happened on instrument number 2, 3, 4, 5, and 7. On instrument number 6 , the problem was also the same with another instruments, however on this instrument the number of subject was singular thus the to be should be $i s$.

\section{Addition}

Table 2. Addition

\begin{tabular}{|l|l|l|l|}
\hline No & Error & Correction & Frequency \\
\hline 1 & It's hakim your friend? & Is hakim your friend? & 3 \\
\hline 2 & So many books on this bag. & There are many books in the bag. & 1 \\
\hline 3 & We are really not innocent. & We are innocent. & 1 \\
\hline \multicolumn{2}{|l}{ TOTAL } & 5 \\
\hline
\end{tabular}

In this type of error, it was found out that there were 3 errors. The frequency of occurrence was 5 times. The errors in Addition occurred by the addition of morpheme that should not be appeared in the construction. From the table above the addition made by the students was on the addition of some morphemes that should not be there such as it, so, and really.

Misformation

Table 3. Misformation

\begin{tabular}{|l|l|l|l|}
\hline No & Error & Correction & Frequency \\
\hline 1 & I'am not a criminal. & I'm not a criminal. & 1 \\
\hline 2 & I'am a crime journalist. & I'm a crime journalist. & 1 \\
\hline 3 & $\begin{array}{l}\text { There is three victims of this } \\
\text { incident. }\end{array}$ & $\begin{array}{l}\text { There are three victims in this } \\
\text { incident. }\end{array}$ & 3 \\
\hline 4 & Is the judges your friend? & Are the judges your friends? & 4 \\
\hline 5 & Is she have enough time? & Does she have enough time? & 6 \\
\hline 6 & $\begin{array}{l}\text { Andi and Susan is not } \\
\text { always together. }\end{array}$ & $\begin{array}{l}\text { Andi and Susan are not always } \\
\text { together. }\end{array}$ & 3 \\
\hline 7 & $\begin{array}{l}\text { Her lawyer do not attend the } \\
\text { judge. }\end{array}$ & $\begin{array}{l}\text { Her lawyer does not attend the } \\
\text { trial. }\end{array}$ & 4 \\
\hline 8 & Is that judges your friend? & Are the judges your friend? & 3 \\
\hline 9 & $\begin{array}{l}\text { Is you have enough time? } \\
\text { His lawyer is not come to the } \\
\text { courtroom. }\end{array}$ & $\begin{array}{l}\text { Does she have enough time? } \\
\text { trial. }\end{array}$ & 5 \\
\hline 11 & Witness look confident. & The witnesses look confident. & 6 \\
\hline 12 & Defendant feel worried. & The defendant feels worried. & 6 \\
\hline 13 & $\begin{array}{l}\text { The police officers doesn't } \\
\text { in TKP. }\end{array}$ & $\begin{array}{l}\text { The police officers are not at the } \\
\text { crimescene. }\end{array}$ & 7 \\
\hline TOTAL & & 54 \\
\hline
\end{tabular}


In this type of error, there were 13 errors found out and there were 54 frequency of errors appeared from the analysis. This type of error was happened because of the misformation of some morphemes on the instruments. On the first and the second instrument, the errors were found out on the misformation of the morpheme am which was constructed together with the morpheme I. The construction was completely error because the construction was meant to be a short form construction of I'm.

The third, fourth, sixth, and eighth instrument showed up the misformation error in the use of to be. The subject-verb agreement was not constructed correctly. The subjects on the third, fourth, sixth, and eighth instrument were all plural. Therefore, the verbs followed by the subjects were supposed to be in plural. The to be is was supposed to be are.

The fifth, ninth, and tenth instrument also showed up the misformation error. The misformation error occurred in the misformation of the use of to be is. The to be supposed to be replaced by does. It was because of the construction of the sentence which followed the grammatical rules of the simple present tense. The structure of the sentences of instrument number five, nine, and ten were all in the form of stating action which contained verbs. Moreover, the sentences were all in the form of verbal construction. Therefore, the to be is should be replaced by do or does. In this case, it was more suitable to use does based on the number of the subject.

On the seventh instrument, there was found misformation error in the use of morpheme $d o$. The morpheme was not agrreed with the subject. The subject was singular which means that the verb must be agrreed in singular also. Therefore, the morpheme do should be replaced by the morpheme does.

The eleventh instrument appeared to be error in the term of misformation of the use subject. Based on the translation of the instrument, the subject was in plural. Should the subject was in plural, the instrument might be correct. In the other hand, the instrument would have been correct if the verb had been transformed into singular.

The twelfth instrument was also found error in misformation. The reason was almost the same with the elevent instrument. However, in this instrument the subject was singular while the verb that should be agreed was in plural. The correction was need to be made on the verb agreement.

The last misformation error on the thirteenth instrument was found out on the misformed of the use of does. The morpheme was supposed to be are. The sentence was in the form of nominal and not verbal. Therefore, the sentence must follow the rules of subject-verb agreement of the nominal sentence.

Misordering

Table 4. Misordering

\begin{tabular}{|l|l|l|l|}
\hline No & Error & Correction & Frequency \\
\hline 1 & $\begin{array}{l}\text { She does have enough } \\
\text { time? }\end{array}$ & Does she have enough time? & 1 \\
\hline TOTAL & 1 \\
\hline
\end{tabular}


Misordering error appeared to be error that happened because of the misorder of the morphemes in the sentence. In other word, the structure of the words in forming a correct order of a clause or sentence was failed to achieve. Normally, this phenomenon happened to those who has lack knowledge of grammar.

From the analysis, it was found out that there was one error in misordering. The error was identified by the misordered of the word does. The sentence was formed in interogative sentence. Therefore, the verb agreement of the sentence must be placed infront of the sentence. However, the verb agreement here was placed after the subject was then identified as misordering error.

\section{Discussion}

The discussion of this research was mainly divided into three main discussions. The purpose was to answer the research questions of this research. Based on the findings above, all of the error types including omission, addition, misformation, and misordering were found out from the analysis of the second semester students of law faculty's writing. The facts showed that 86 out of 300 instruments were identified error in subject-verb agreement.

Figure 4.2.1 Percentage of Subject-verb Agreement Error

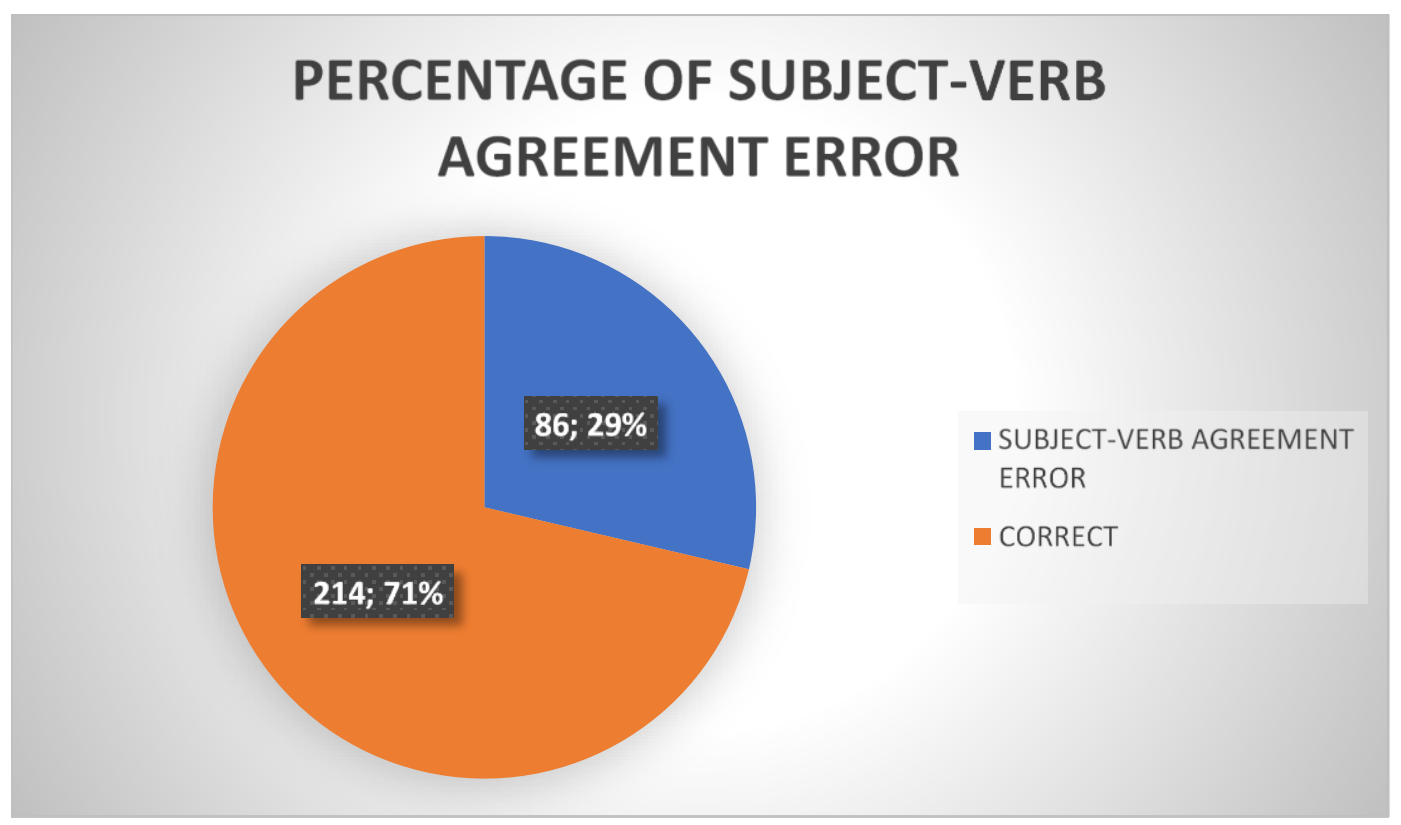

From the findings, it was found out that there were 26 frequency of omission errors, 5 frequency of addition errors, 54 frequency of misformation errors, and 1 frequency of misordering error. 
Figure 4.2.2 Clasification of Error

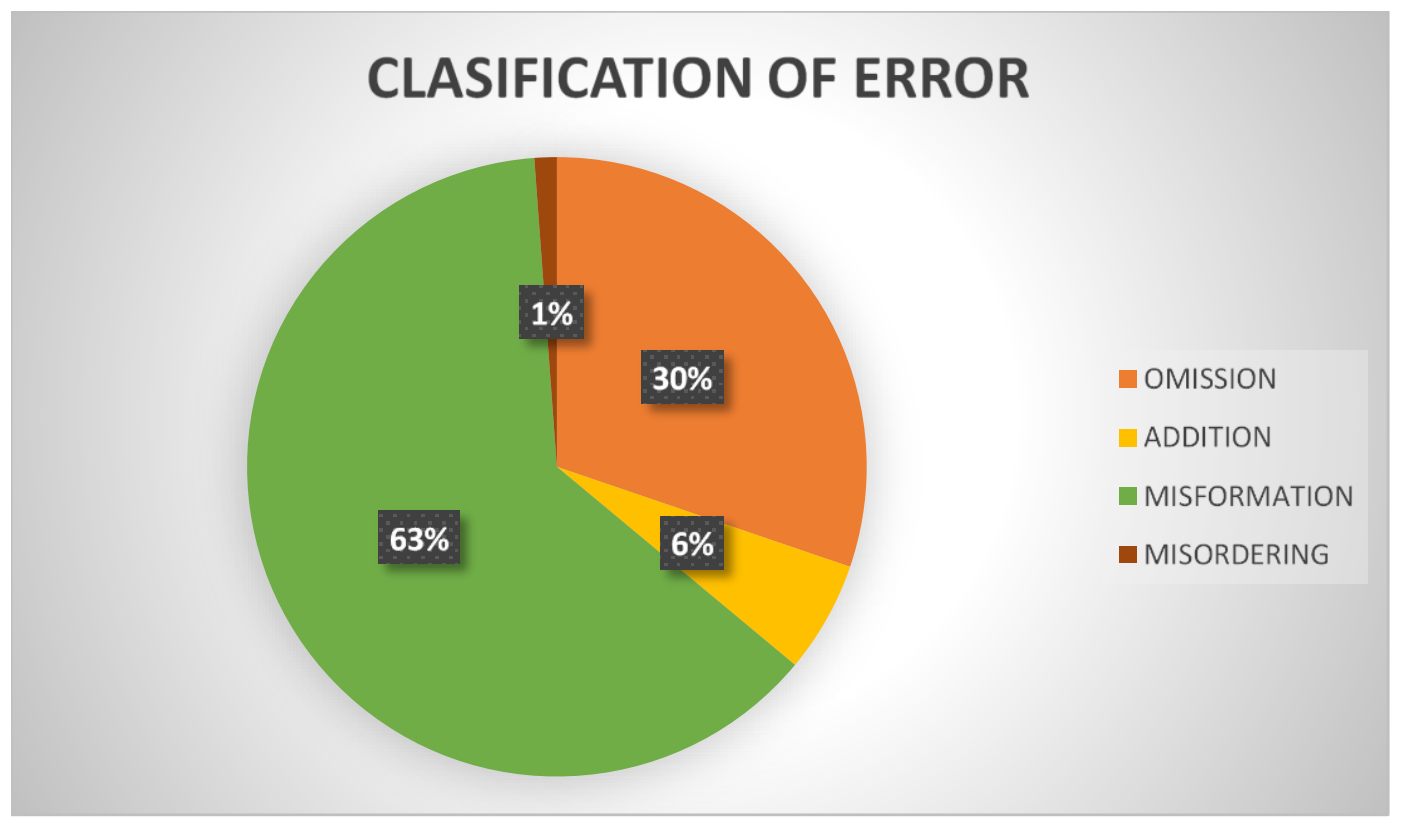

Based on the figure above, the dominan error was dominated by the misformation error. $63 \%$ of the subject-verb agreement errors identified as the misformation error. Omission error was then on the second dominan error appeared in this research with the percentage of $30 \%$. Addition error was on the third place with only $6 \%$. The last was misordering error with only $1 \%$.

After analyzing all of the errors made by the students, there were some possible cause that likely to be the reasons of the errors to be happened. The main cause was because of the lack of the structure mastery. The law faculty of UNIKA Santo Thomas runs English class only on the second semester. This is considered not good enough to build the students' knowledge of basic English not even to mention English for specific purposes as for Legal English.

The students faced troubles in constructing simple sentence which used the most simple tenses among all of the tenses in English which is the Simple Present Tense. The mastery of Simple Present Tense is a must considering the daily use of the language and also as the very foundation of English structure mastery.

From this research, it was found out that the students faced serious problems only to construct good subject-verb agreement. Beside that, the students carelesness was also one of the possible cause of the error. Some students did not pay attention on the construction of the words which constructed in short form. This could be a serious flaw in writing, specially for them who learn English for their carreer as judge, lawyer, etc.

\section{Conclusion}

The conclusions of this research were as follows:

There were 4 kinds of error on subject-verb agreement made by the second semester students of Law Faculty UNIKA Santo Thomas Medan in constructing Simple Present Tense. They were omission error, addition error, misformation error, and misordering error.

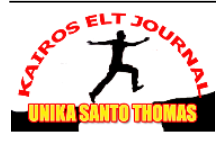


Misformation error was the most dominan error on subject-verb agreement made by the second semester students of Law Faculty UNIKA Santo Thomas Medan in constructing Simple Present Tense. There were 54 frequency of misformation errors identified from the students' worksheet.

The possible cause of the subject-verb agreement error made by the students of Law Faculty in UNIKA Santo Thomas Medan in constructing simple present tense was because of the students did not have enough understanding of the simple present tense.

\section{Suggestion}

There were several suggestions made in order to avoid such errors that had been made by the students. They were as follows:

The students were suggested to learn more about the construction of the subjectverb agreement based on the type of sentences.

The students were suggested to learn more about the simple present tense both from its structure and functions.

The Faculty of Law was suggested to add more English subject on their curricullum to let the students have more time and effort in understanding basic English structure and enough vocabulary of Legal English.

\section{REFERENCES}

Arikunto, S. 2006. Dasar-dasar Evaluasi Penilitian Pendidikan Jakarta: Bumi Aksara.

As'ari, M.Y. 2013. An Error Analysis on Subject-Verb Agreement of Written English by 11th

Grade Students of Man 3 Tulungagung. Universitas Brawijaya. Jurnal Ilmiah Mahasiswa FIB Vol 2, No 3

Belmont and Sharkey. 2011. The Easy Writer: Formal Writing for Academic Purposes, $3^{\text {rd }}$ Edition. Australia.

Brown, D.H. 1980. Principles of Language Learning and Teaching. United States of America.

Brucem, I. 2008. Academic Writing and Genre. New York.

Chandler, D. 2000. An Introduction to Genre Theory. Australia.

Devitt, A. 2004. Writing Genres. Southern Illinois University.

Elder, S. 2009. ILO school to work transition survey: A methodological guide. International Labour Organization.

Handcock and Gile. August 2011. On the Concept of Snowball Sampling.England.

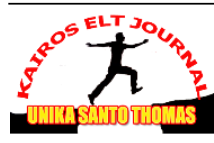


Khansir, A.A. May 2012. Error Analysis and Second Language Acquisition. Finland.

Knapp and Watkins. 2005. Genre, Text, Grammar. Australia: University of New South Wales.

Llach, A.P.M. 2011. Lexical Errors and Accuracy in Foreign Language Writing. Ireland: Trinity College.

Mali, Y.C.G. 2012. Students' Subject-Verb Agreement Errors in Paragraph Writing Class. LLT

Journal: A Journal on Language and Language Teaching Vol 15, No 2

Mertens, N. 2010. Writing: Processes, Tools, and Techniques. New York: Nova Science Publisher.

Rizka, H and Hidayati, N.N. 2015. Mega Bank of Grammar. Yogyakarta: Pustaka Baru Press.

Sugiyono. 2012. Metode Penelitian Administrasi. Bandung: Alfabeta.

Suprapto. 2013. Metodologi Pendidikan: Ilmu pendidikan dan Ilmu-Ilmu Pengetahuan Sosial. Jakarta: PT. Buku Seru.

Wahyudi, Ribut (2012) Error analysis on subject-verb agreement: The case of a University Student in Indonesia. Research on Humanities and Social Sciences, 2 (4). pp. 20-25. ISSN 2224-5766 